\title{
Analisis Dampak Siklon Tropis Nangka, Parma dan Nida pada Distribusi Curah Hujan di Sulawesi Utara
}

\author{
Ratih Prasetya, ${ }^{1, *}$ As'ari, ${ }^{2}$ dan Wan Dayantolis ${ }^{3}$

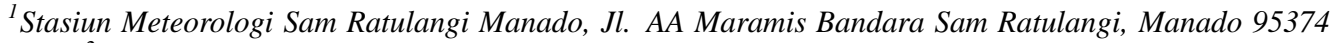 \\ ${ }^{2}$ Jurusan Fisika Universitas Sam Ratulangi Manado, Kampus Unsrat, Bahu Manado 95115 \\ ${ }^{3}$ Stasiun Klimatologi Manado, Stasiun Klimatologi Kelas II Kayuwatu, Manado
}

\begin{abstract}
Intisari
Salah satu fenomena atmosfer skala Meso yang berpengaruh pada dinamika cuaca skala lokal adalah siklon tropis. Siklon tropis terbentuk pada lintang antara $10^{\circ}$ dan $20^{\circ}$ dari ekuator. Sebagian besar siklon tropis (67\%) terjadi di belahan bumi utara. Pertumbuhan siklon tropis yang terjadi di belahan bumi utara merupakan salah faktor yang mempunyai dampak signifikan terhadap distribusi hujan di Sulawesi Utara karena letak geografisnya. Sehingga kajian mengenai siklon tropis yang terjadi di belahan bumi utara sangat diperlukan dalam memahami kondisi cuaca. Tahap tumbuh siklon yang mempengaruhi distribusi hujan di Sulawesi Utara berbeda-beda tergantung karakteristik siklon dan kondisi atmosfernya. Sifat hujan yang terjadi sebagai akibat adanya siklon juga berbeda-beda tergantung karakteristik masing-masing siklon dan kondisi masing-masing wilayah.
\end{abstract}

\begin{abstract}
A meso scale atmospheric phenomena that affects the dynamics of weather is tropical cyclone. Tropical cyclone formed in the equatorial latitude of $10^{\circ}$ and $20^{\circ}$. Most of tropical cyclones $(67 \%)$ occured in northern hemisphere. The growth of tropical cyclone that occured in northern hemisphere is one factor that has significant impact on rainfall distribution in North Sulawesi according to its geographical location. So the study of tropical cyclone occured in Northern Hemisphere is required to comprehend the weather condition. The cyclone's growth stage that affects the rainfall distribution in North Sulawesi is vary depends on the cyclone's characteristic and it's atmospheric condition. The rainfall characteristic that occurs as a result of cyclone is also vary depends on the characteristic of each cyclone and the conditions of each location.
\end{abstract}

KATA KUNCI: tropical cyclone, rainfall, distribution

\section{PENDAHULUAN}

Siklon tropis adalah salah satu fenomena skala regional yang muncul di samudera tropis. Siklon tropis (disebut juga Typhoon atau Hurricane atau Tropical Cyclone) merupakan pusaran siklonal sistem cuaca pada daerah tekanan rendah yang berkembang di daerah perairan tropis yang hangat dengan suhu permukaan lut diatas $27^{\circ} \mathrm{C}$ [1].

Siklon tropis muncul di samudera tropis yang disertai dengan angin dahsyat berputar dan hujan sangat lebat. Pelepasan panas kondensasi oleh awan konvektif dalam siklon merupakan sumber energi utama siklon tropis. Kebanyakan siklon tropis terbentuk pada daerah lintang antara $10^{\circ}$ dan $20^{\circ}$ dari ekuator. Sebagian besar siklon tropis $(67 \%)$ terjadi di Belahan Bumi Utara (BBU) [2].

Pertumbuhan siklon tropis pada umumnya dipicu oleh adanya gangguan konvektif yang dikenal sebagai kluster awa, yang pengaruh dari gaya Coriolis dan gaya gravitasi membentuk sistem sirkulasi terpisah melalui beberapa tahapan

\footnotetext{
*E-MAIL: prasetyaratih@ymail.com
}

perkembangan [3].

Tiga syarat penting untuk pertumbuhan siklon tropis, yaitu:

1. Adanya wilayah perairan yang luas dengan suhu muka laut yang cukup tinggi, yaitu lebih dari $27^{\circ} \mathrm{C}$ sehingga udara dapat terangkat dari lapisan atmosfer paling bawah.

2. Harga parameter Coriollis lebih besar dari harga minimum tertentu pada daerah lintang $5-8^{\circ}$ LU dan 5-8 LS.

$$
F_{c}=f_{x}, f=2 \Omega \sin \Phi
$$

dengan $\omega$ adalah kecepatan sudut rotasi bumi $(7,29$ $\left.\times 10^{-5} \mathrm{rad} / \mathrm{sekon}\right), \Phi$ adalah lintang tempat, $\mathrm{x}=\mathrm{ke}-$ cepatan angin $(\mathrm{m} / \mathrm{s}), \mathrm{f}=$ parameter Coriolis.

3. Adanya wind shear vertikal yang lemah [4]. Arah pergerakan siklon tropis tidak tentu. Seringnya siklon tropis bergerak kearah barat dan terkadang kearah kutub setelah pembentukan awalnya [5].

Dampak siklon tropis dipengaruh posisi dan intensitas siklon dan juga tergantung pula pada faktor sirkulasi udara di wilayah Indonesia. Terkadang ketika ada indikasi tumbuh 


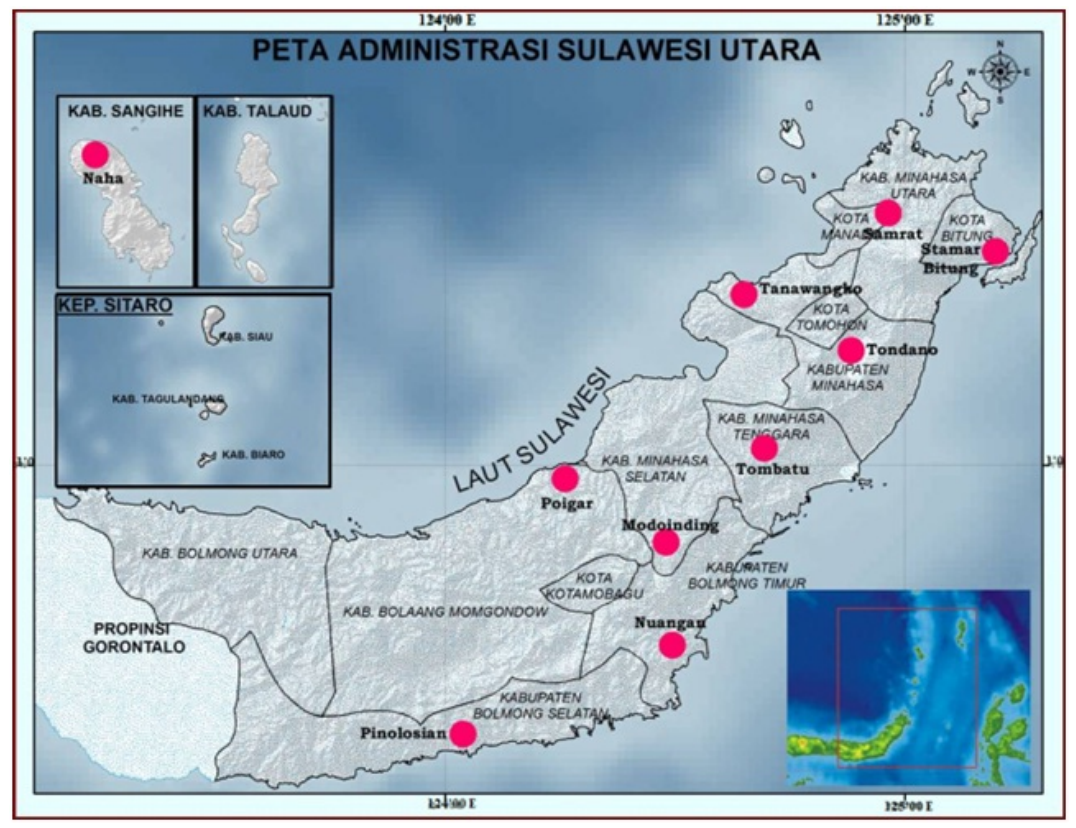

Gambar 1: Lokasi penelitian.

siklon, pada beberapa wilayah kecenderungan cuacanya terlihat memburuk. Tapi ketika siklon itu sudah matang atau sudah diberi nama (kecuali daerah yang mempunyai radius $500 \mathrm{~km}$ dari pusat siklon yang lebih sering mengalami hujan lebat), yang timbul di Indonesia justru hanya angin kencang dan gelombang tinggi. Kemudian disaat siklon tersebut sudah menjauhi wilayah Indonesia atau ketika intensitasnya sudah melemah justru cuaca di Indonesia bagian selatan cenderung banyak hujan lebat [6].

Sulawesi Utara, merupakan wilayah Indonesia di BBU yang berbatasan dengan samudra Pasifik bagian barat di mana siklon tropis di BBU sering terjadi. Selama tahun 2009 tercatat terjadi 20 kali siklon tropis di BBU dengan posisi dan intensitas yang berbeda-beda. Pada tulisan ini akan menyajikan analisis dampak tiga siklon tropis yaitu Nangka, Parma dan Nida dari 20 silon tropis yang terjadi pada 2009. Analisis difokuskan pengaruhnya terhadap distribusi curah hujan yang terbentuk pada saat ketiga siklon tropis tersebut terjadi.

\section{METODE PENELITIAN}

Data yang digunakan dalam tulisan ini meliputi

1. Data curah hujan harian pada bulan Juni sampai Desember tahun 1999-2009 pada 10 titik di Sulawesi Utara Manado, Bitung, Tondano, Naha, Tombatu, Tanawangko, Poigar, Modoinding, Pinolosian dan Nuangan. Data diperoleh dari Stasiun Klimatologi Manado

2. Data siklon tropis yang terjadi di Belahan Bumi Utara yang terjadi pada bulan Juni hingga Desember 2009 mencakup waktu terjadinya, tahap pertumbuhan, tekanan, serta kecepatan angin [7] .
3. Peta streamline [8].

4. Citra satelit [9].

Data tahun 1999-2008 disusun menjadi rata-rata 5 harian (pentad) dan dijadikan sebagai pembanding terhadap curah hujan pentad pada tahun 2009. Jika perbandingan kurang dari $100 \%$ berarti curah hujan pentad pada 2009 berkurang dan jika lebih dari $100 \%$ berarti curah hujan pentad pada 2009 bertambah.

Hasil perbandingan tersebut kemudian dipetakan secara spasial menggunakan aplikasi GIS untuk mengetahui sebaran prosentasi curah hujannya. Lokasi penelitian ditunjukkan Gambar 1.

\section{HASIL DAN PEMBAHASAN}

Selama tahun 2009 tercatat 20 kali kejadian siklon tropis di BBU dengan pusat, skala dan masa hidup siklon yang berbeda-beda. Data tersebut disederhanakan seperti terlihat pada Tabel I.

Berdasarkan Tabel I terlihat bahwa siklon tropis mulai terjadi sejak bulan Juni 2009. Hal ini seiring dengan pergerakan semu matahari yang berada di utara ekuator sehingga memberikan energi maksimum di lautan wilayah utara ekuator sebagai pemicu terbentuknya siklon tropis .

Secara umum pada bulan April hingga bulan September pola angin yang melintas di atas wilayah Sulawesi Utara adalah monsun Australia yang bertiup dari arah timur hingga tenggara. Monsun Australia berasosiasi dengan terjadinya kemarau di Indonesia. Setelah bulan September pola angin yang aktif adalah monsun Asia. Pola ini akan bertahan hingga bulan April berikutnya. Monsun Asia berasosiasi dengan terjadinya musim hujan di Indonesia. 
TABEL I: Daftar Kejadian siklon tropis Tahun 2009 [7]

\begin{tabular}{|c|c|c|c|c|c|c|}
\hline \multirow{2}{*}{ No } & \multirow{2}{*}{$\begin{array}{l}\text { Nama } \\
\text { Siklon }\end{array}$} & \multirow{2}{*}{$\begin{array}{l}\text { Tek. } \\
\text { Min }\end{array}$} & \multicolumn{4}{|c|}{ Masa Hidup } \\
\hline & & & $\begin{array}{r}\text { Mu } \\
\text { Bulan }\end{array}$ & & $\begin{array}{r}\mathrm{Ha} \\
\text { Bulan }\end{array}$ & $\begin{array}{l}\text { bis } \\
\text { Tgl }\end{array}$ \\
\hline 1 & LINFA & 975 & 6 & 17 & 6 & 30 \\
\hline 2 & NANGKA & 994 & 6 & 22 & 6 & 26 \\
\hline 3 & SOUDELOR & 992 & 7 & 9 & 7 & 12 \\
\hline 4 & MOLAVE & 975 & 7 & 15 & 7 & 19 \\
\hline 5 & GONI & 990 & 8 & 1 & o & 10 \\
\hline 6 & MARAKOT & 945 & 8 & 2 & 8 & 12 \\
\hline 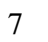 & ETAU & 992 & 8 & 8 & 8 & 16 \\
\hline 8 & VAM & 945 & 8 & 16 & 8 & 26 \\
\hline 9 & KROV & 975 & 8 & 28 & 9 & 2 \\
\hline 10 & DUJ & 980 & 9 & 2 & 9 & 11 \\
\hline 11 & MUJIG & 994 & 9 & 9 & 9 & 11 \\
\hline 12 & $\mathrm{CHOI}$ & 915 & 9 & 12 & 9 & 20 \\
\hline 13 & KOPPU & 975 & 9 & 13 & 9 & 15 \\
\hline 14 & KETSANA & 960 & 9 & 25 & 9 & 30 \\
\hline 15 & PARMA & 930 & 9 & 27 & 10 & 14 \\
\hline 16 & MELOR & 910 & 9 & 29 & 10 & 11 \\
\hline 17 & NEPARTAK & 992 & 10 & 8 & 10 & 15 \\
\hline 18 & LUPIT & 930 & 10 & 14 & 10 & 30 \\
\hline 19 & MIRIN & 955 & 10 & 25 & 11 & 2 \\
\hline 20 & NIDA & 905 & 11 & 21 & 12 & J \\
\hline
\end{tabular}

Sejak Juni 2009 iklim di Indonesia dipengaruhi oleh berlangsungnya fenomena El Nino [10] yang dampaknya juga terjadi di Sulawesi Utara. Pada fase El Nino umumnya akan menyebabkan terjadi penurunan curah hujan di wilayah Indonesia.

\section{Siklon Tropis Nangka}

Masa hidup siklon tropis berlangsung selama 4 hari yaitu sejak tanggal 22 hingga 26 Juni 2009. Tekanan minimum di pusat siklon ini berkisar $994 \mathrm{mb}$. Mulai terbentuk pada $10,8^{\circ}$ LU dan $129,0^{\circ} \mathrm{BT}$. Arah pergerakan ke arah barat laut dengan kecepatan angin maksimum 45 knot.

siklon tropis Nangka ini berawal dari sistem tekanan rendah pada tanggal 22 Juni 2009 di sebelah timur Pulau Mindanau Philipina. Berkembang dan bergerak dengan lambat kearah Barat - Barat Laut hingga akhirnya berkembang menjadi siklon tropis di Philipina pada tanggal 23 Juni dengan tekanan $994 \mathrm{hPa}$. Pada siang hari di tanggal tersebut sudah terlihat adanya mata/eye pada pola perawanannya. Pola mata ini berkembang dan bertahan hingga malam hari dimana pola ini semakin tidak jelas lalu perawanan menyebar hingga akhirnya punah. Selama siklon tropis Nangka mulai memasuki kategori Badai Tropis hingga melemah dan akhirnya punah, angin yang terjadi memiliki kecepatan hingga 40 knot. Siklon tropis Nangka semasa hidupnya memiliki kecepatan angin pada kisaran 35 hingga 40 knot. Puncak intensitas terjadi pada tanggal 23 Juni dengan tekanan di pusat adalah 994 hPa. Kondisi intensitas maksimum ini bertahan selama 2 hari hingga tanggal 25 Juni sebelum akhirnya turun menjadi 35 knot pada siang harinya. Pergerakan siklon tropis Nangka pada tanggal 22 Juni sejak teridentifikasi sebagai sistem tekanan rendah yaitu ke arah Barat dengan lambat menuju Laut Cina Selatan.

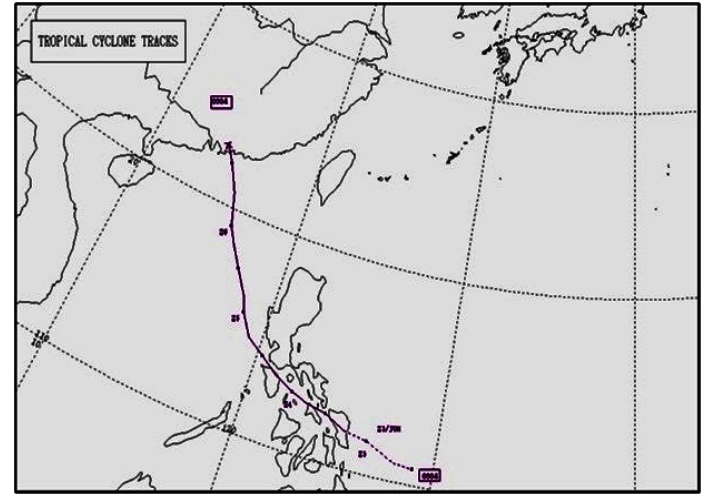

Gambar 2: Peta lintasan siklon tropis Nangka [7].

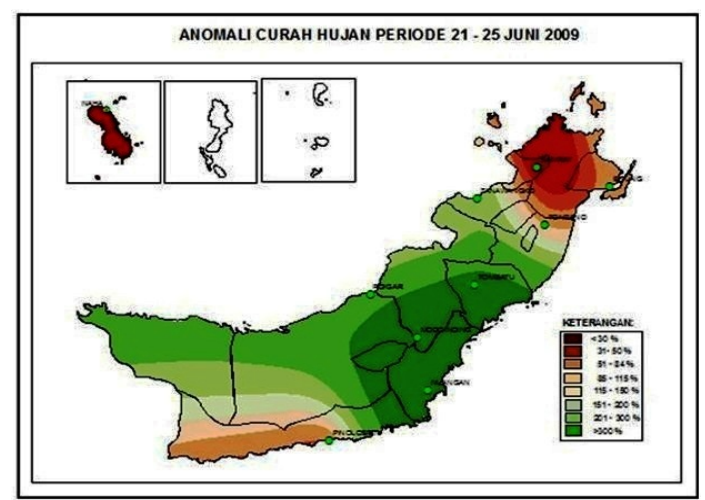

Gambar 3: Anomali curah hujan periode 21 - 25 Juni 2009 [8].

Siklon tropis Nangka lalu bergerak ke arah Barat Laut dengan kecepatan 35 hingga 40 knot. Saat siklon tropis Nangka berkembang lebih intensif ke arah Barat Laut dan akhirnya melemah menjadi sistem tekanan rendah lalu punah setelah masuk daratan Cina pada tanggal 26 Juni [11].

Pada tahap punah, secara umum siklon tropis ini memberikan dampak tidak langsung terhadap kondisi cuaca buruk berupa hujan lebat dan gelombang tinggi di beberapa wilayah Sulawesi Utara. Sedangkan pada saat memasuki kategori tumbuh hingga dewasa pengaruh yang diberikan berkurang terhadap wilayah Sulawesi Utara.

Pada fase awal pertumbuhan yaitu sistem tekanan rendah hingga badai tropis (Tropical Storm) peningkatan curah hujan $>150 \%$ terjadi pada wilayah Sulawesi Utara bagian tengah meliputi Tombatu dan Modoinding, Sulawesi Utara bagian utara meliputi Tanawangko dan Poigar serta Sulawesi Utara bagian selatan yaitu Nuangan. Terlihat pula wilayah Sulawesi Utara bagian utara meliputi Manado, dan Sangihe, Sulawesi Utara bagian tengah yaitu Tondano, Bitung dan Sulawesi bagian selatan yaitu Pinolosian mengalami pengurangan curah hujan hingga di bawah normalnya sebagaimana terlihat pada Gambar 3.

Pada tanggal 22 Juni 2009, terbentuk pusat tekanan rendah yang memusat dan memutar di Samudera Pasifik sebelah barat Philipina yaitu siklon tropis Nangka. Pengaruh siklon tropis Nangka ini lebih dominan menambah curah hu- 


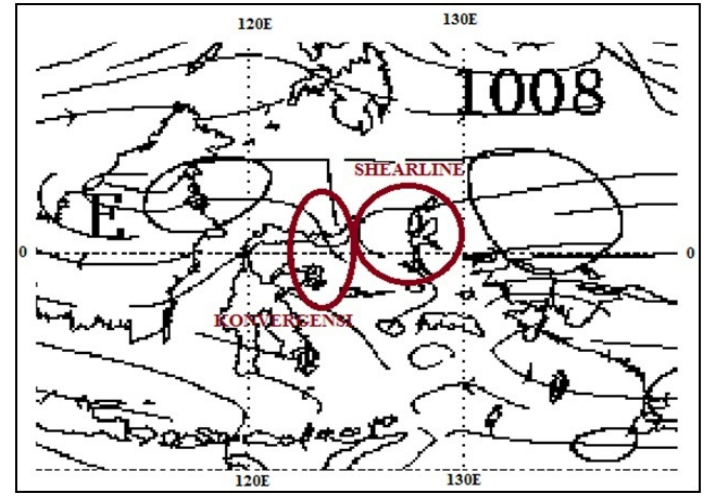

Gambar 4: Pola angin tanggal 22 Juni 2009 [9].

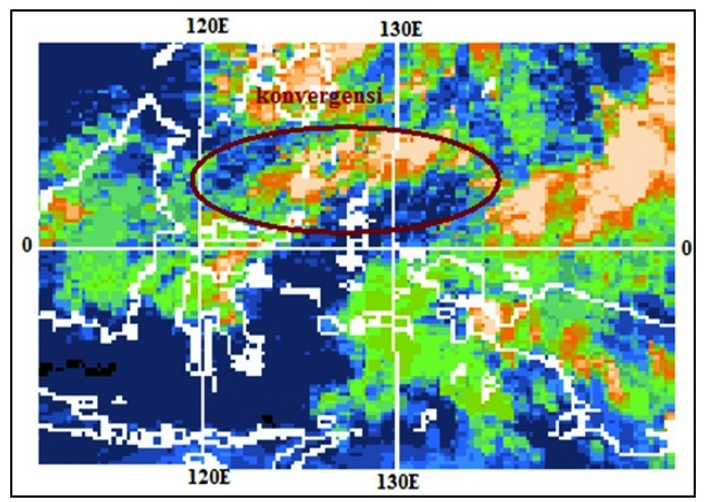

Gambar 5: Citra satelit tanggal 22 Juni 2009 pukul 15.00 UTC [9].

jan di Sulawesi Utara bagian tengah karena pola angin konvergen dan shearline (pada peta pola angin ditandai dengan lingkaran merah) yang disebabkannya. Siklon ini ditambah dengan adanya tekanan rendah di atas wilayah Kalimantan juga menarik awan-awan yang berada diatas Sulawesi Utara bagian Utara sehingga menyebabkan pola angin divergen diatas wilayah tersebut (Gambar 4). Akibatnya wilayah Sulawesi Utara bagian Utara berpeluang cerah hingga berawan seperti terlihat pada citra satelit cuaca (Gambar 5).

Pada fase punah yaitu melemahnya menjadi sistem tekanan rendah terjadi peningkatan curah hujan di Sulawesi Utara bagian utara meliputi Manado, Poigar dan Tanawangko dan Sulawesi Utara bagian tengah yaitu Modoinding dan Bitung serta penurunan curah hujan di bagian Selatan (Gambar 6).

Pengaruh siklon tropis Nangka pada fase ini lebih dominan menambah curah hujan di Sulawesi Utara bagian Utara dan Tengah karena pola angin shearline yang disebabkannya (Gambar 7). Siklon ini juga menarik awan-awan yang berada diatas wilayah Sulawesi Utara bagian Selatan sehingga menyebabkan pengurangan curah hujan di wilayah tersebut dengan keadaan cuaca cerah hingga berawan. (Gambar 8).

\section{Siklon Tropis Parma}

Siklon tropis Parma memiliki durasi hidup yang cukup lama yaitu berlangsung selama 17 hari yaitu sejak tanggal 27

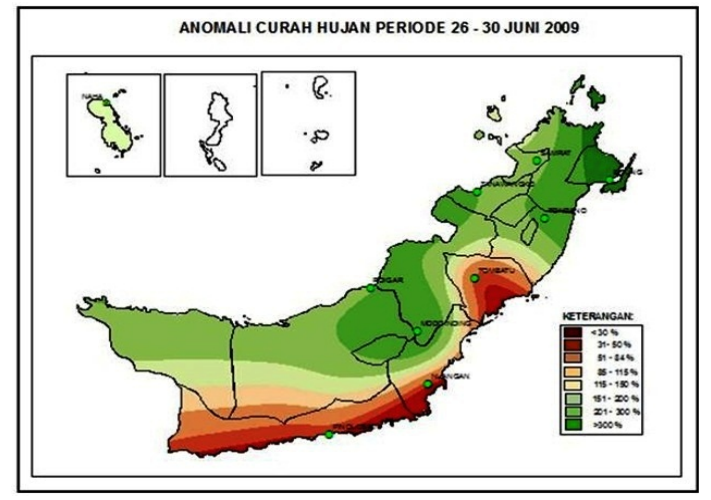

Gambar 6: Anomali curah hujan periode 26 - 30 Juni 2009.

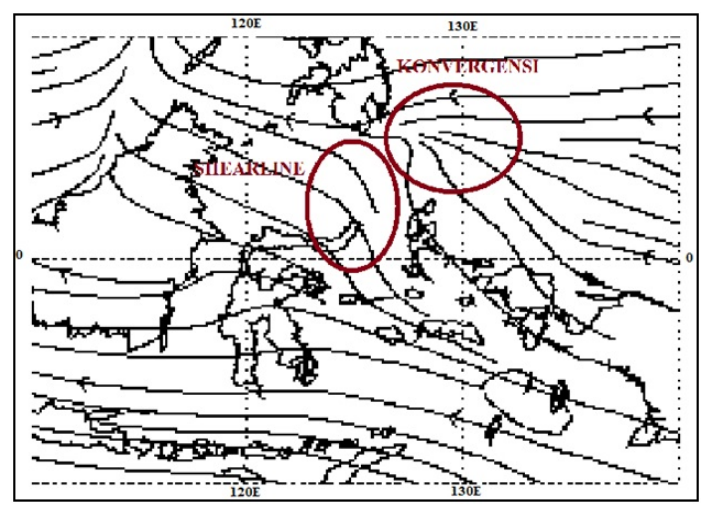

Gambar 7: Pola angin tanggal 26 Juni 2009 [8].

September hingga 14 Oktober 2009. Tekanan minimum di pusat siklon ini berkisar $930 \mathrm{mb}$. Mulai terbentuk pada $9,4^{\circ}$ LU dan $145,5^{\circ} \mathrm{BT}$. Arah pergerakan ke arah barat laut dengan kecepatan angin maksimum 100 knot.

Siklon tropis Parma ini teridentifikasi pertama kali sebagai sistem tekanan rendah pada tanggal 27 September 2009 di Samudera Pasifik sebelah Utara Papua. Pada tanggal 29 September sistem tekanan rendah ini berkembang ke dalam tahap Badai Tropis (Tropical Storm). Intensitas kecepatan anginnya pada tahap awal mencapai hingga 35 knot den-

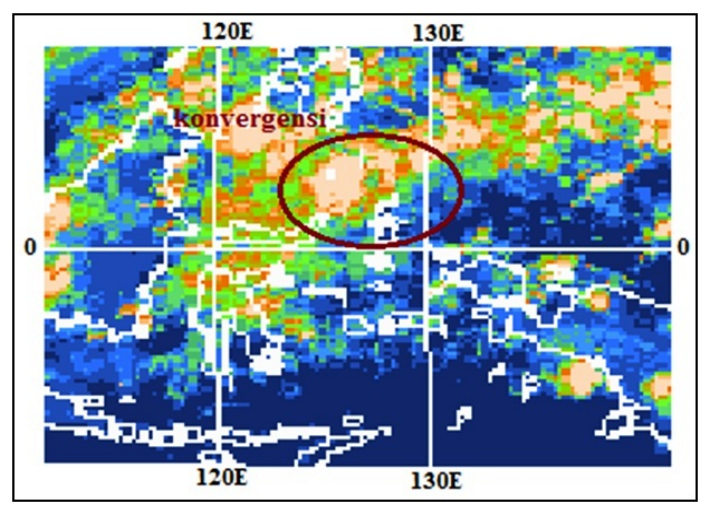

Gambar 8: Citra satelit tanggal 26 Juni 2009 pukul 21.00 UTC [9]. 


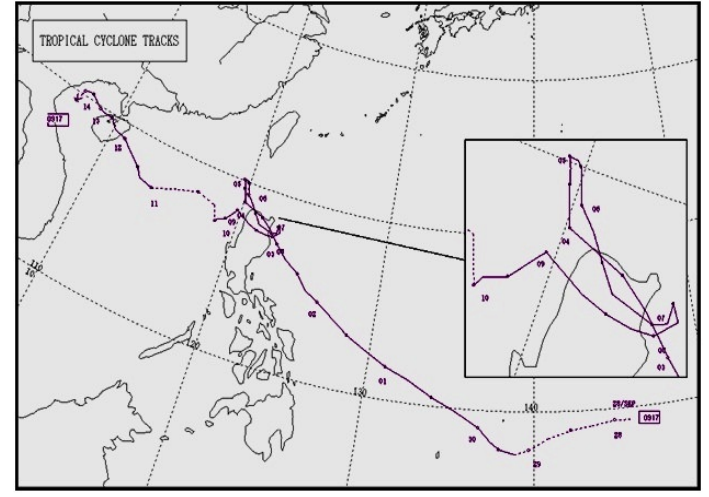

Gambar 9: Arah pergerakan siklon Parma [7].

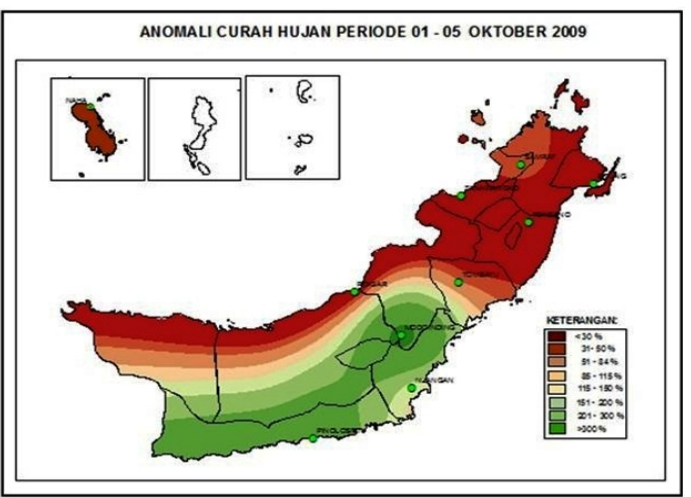

Gambar 10: Anomali curah hujan periode 01 - 05 Oktober 2009.

gan pergerakan ke arah Barat menuju sebelah utara Philipina. Pada awal periode tumbuh hingga kondisi puncak tercapai pola angin yang terbentuk di atas Sulawesi Utara yang diakibatkannya memiliki pengaruh tidak langsung yang cukup signifikan. Keadaan vortisitas yang baik dan suplai massa udara yang cukup banyak menyebabkan siklon tropis Parma memiliki masa hidup yang cukup lama yaitu 17 hari. Pada tanggal 30 September siklon tropis Parma mencapai tahap puncaknya yaitu Typhoon dan memiliki intensitas tertinggi dengan kecepatan angin pada sekeliling pusat sistem mencapai 100 knot dengan tekanan $930 \mathrm{hPa}$ pada tanggal 1 Oktober. Pada sore harinya Parma mulai melemah. Pada tanggal 07 Oktober siklon tropis Parma melemah menjadi depresi tropis dan menguat kembali pada tanggal 08 Oktober di atas wilayah Laut Cina Selatan. Pada siang hari tanggal 14 Oktober Parma melemah hingga akhirnya punah saat memasuki wilayah Vietnam [11] (Gambar 9).

Pada tahap siklon tropis Parma tumbuh dan dewasanya peningkatan curah hujan $>150 \%$ atau diatas normal terjadi pada sebagian wilayah Sulawesi Utara bagian tengah dan selatan meliputi Modoinding, Nuangan dan Pinolosian. Terlihat pula wilayah Sulawesi Utara bagian utara dan sebagian wilayah Sulawesi Utara bagian tengah meliputi Manado, Bitung, Tondano, Tanawangko, Tombatu, Poigar serta Sangihe mengalami penurunan curah hujan hingga di bawah normalnya sebagaimana terlihat pada Gambar 10.

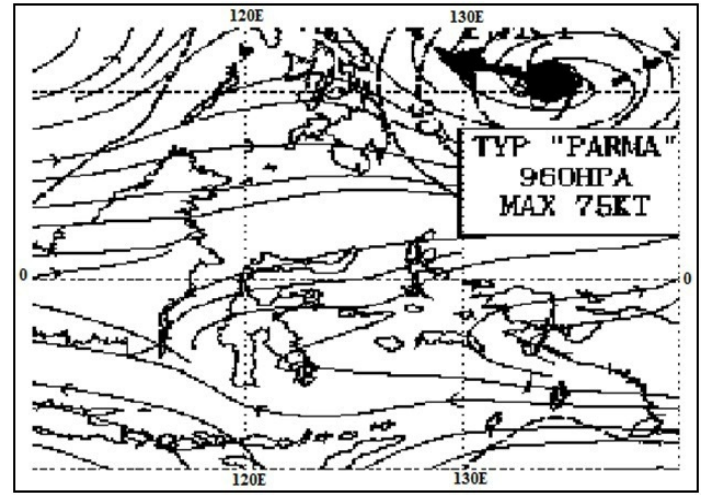

Gambar 11: Pola angin tanggal 30 September 2009 [8].

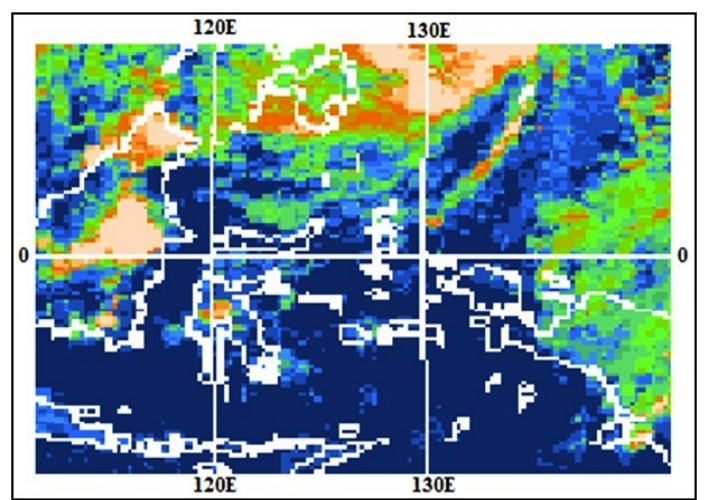

Gambar 12: Citra satelit tanggal 30 September 2009 pukul 12.00 UTC [9].

Terbentuknya pusat tekanan rendah yang memusat dan memutar di Samudera Pasifik sebelah barat Philipina yaitu siklon tropis Parma lebih dominan menambah curah hujan di Sulawesi Utara bagian selatan karena pola angin yang disebabkannya. Adanya tekanan yang sangat rendah pada pusat siklon ini menyebabkannya menarik awan-awan yang berada disekitarnya terutama diatas Sulawesi Utara bagian utara dan tengah (Gambar 11). Akibatnya wilayah tersebut memiliki kecenderungan cuaca baik yang mengurangi potensi hujan (Gambar 12).

Masih pada tahap yang sama juga terjadi peningkatan curah hujan di sebagian besar Sulawesi Utara bagian utara, tengah dan selatan serta penurunan curah hujan di sebagian kecil Sulawesi Utara bagian selatan dan utara (Gambar 13).

Pola angin memperlihatkan adanya daerah pola angin konvergensi dan shearline (Gambar 14) yang terlihat pada citra satelit (Gambar 15) menyebabkan adanya konsentrasi massa udara pada sebagian besar wilayah Sulawesi Utara.

Pada tahap punah curah hujan lebih banyak berkurang di sebagian besar wilayah Sulawesi Utara. Hanya sebagian kecil wilayah Sulawesi Utara terutama bagian utara dan tengah mengalami penambahan curah hujan (Gambar 16).

Pola angin pada peta streamline memperlihatkan adanya daerah divergensi yang menyebabkan penyebaran massa udara sehingga curah hujan di sebagian besar wilayah 


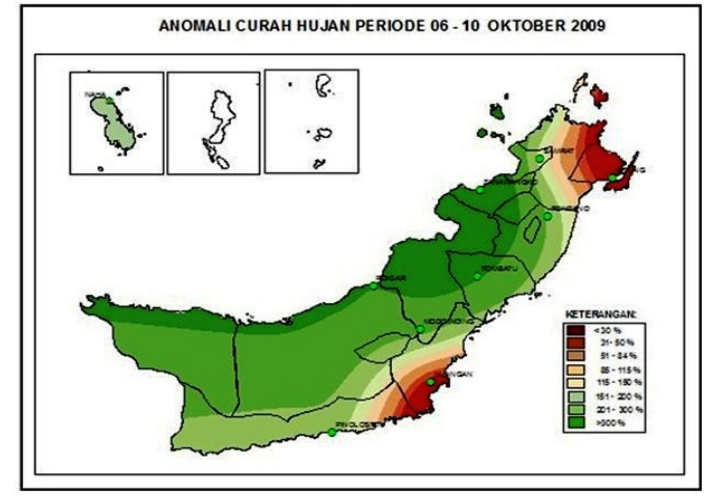

Gambar 13: Anomali curah hujan periode 06 - 10 Oktober 2009.

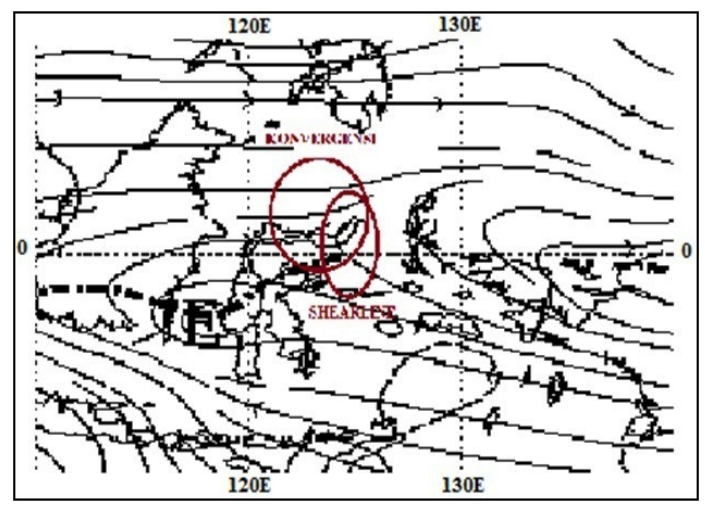

Gambar 14: Pola angin tanggal 07 Oktober 2009 [8].

Sulawesi Utara berkurang seperti pada wilayah Manado, Tanawangko, Tombatu, Modoinding, Poigar Pinolosian dan Sangihe (Gambar 17). Citra satelit menunjukkan adanya konsentrasi massa udara di laut sekitar Sulawesi Utara terutama Laut Maluku karena adanya shearline (belokan angin) sebagai akibat adanya divergensi dan berdampak pada bertambahnya curah hujan di sebagian kecil wilayah Sulawesi Utara bagian utara dan tengah yaitu Tondano, Tombatu, Bitung dan Nuangan (Gambar 18).

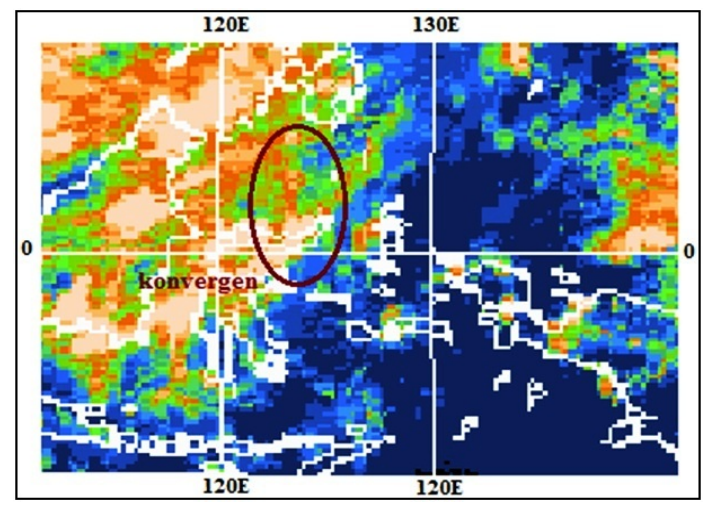

Gambar 15: Citra satelit tanggal 07 Oktober 2009 pukul 09.00 UTC [9].

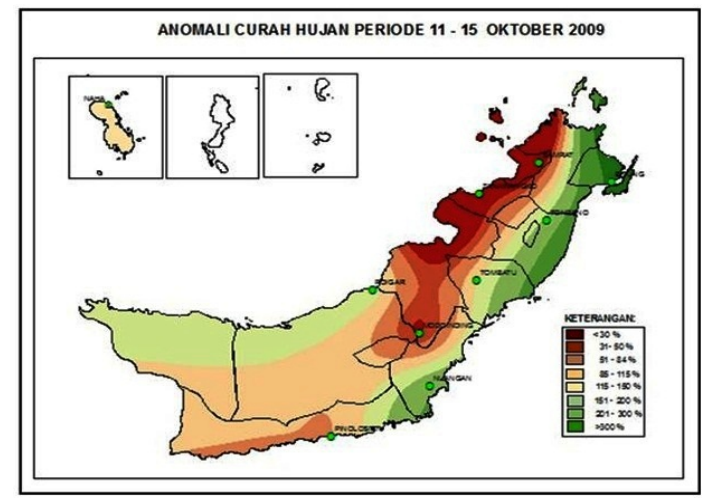

Gambar 16: Anomali curah hujan periode 11 - 15 Oktober 2009.

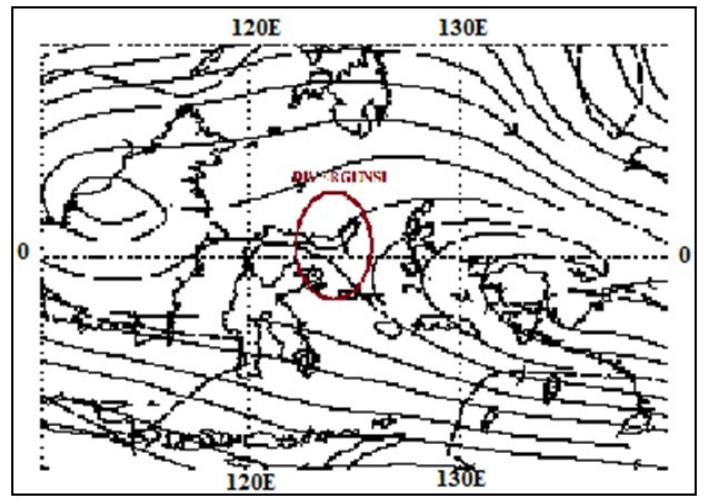

Gambar 17: Pola angin tanggal 11 Oktober 2009 [8].

\section{Siklon Tropis Nida}

Masa hidup siklon tropis Nida berlangsung selama 12 hari yaitu sejak tanggal 21 November hingga 03 Desember 2009. Tekanan minimum di pusat siklon ini berkisar $905 \mathrm{mb}$. Mulai terbentuk pada $6,7^{\circ} \mathrm{LU}$ dan $148,3^{\circ}$ BT. Arah pergerakan ke arah barat laut dengan kecepatan angin maksimum 105 knot.

Siklon tropis Nida terbentuk di Samudra Pasifik sebe-

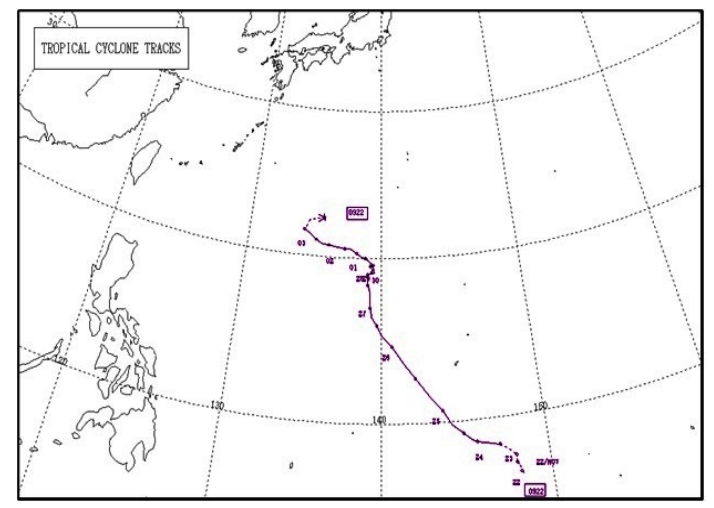

Gambar 18: Citra satelit tanggal 11 Oktober 2009 pukul 00.00 UTC [9]. 


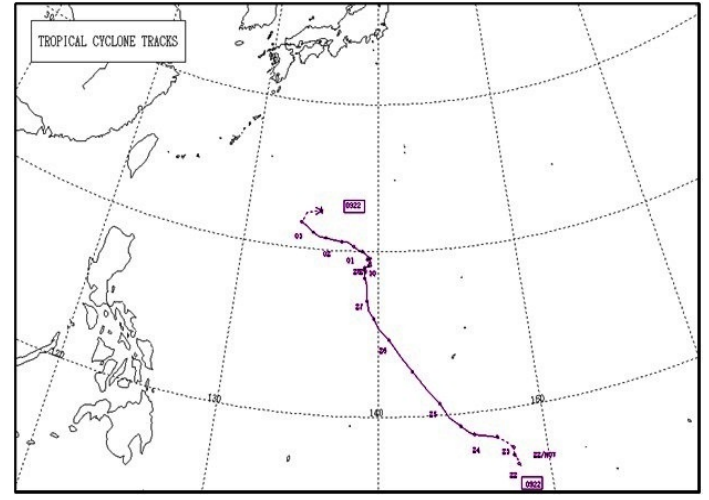

Gambar 19: Arah pergerakan siklon Nida [7].

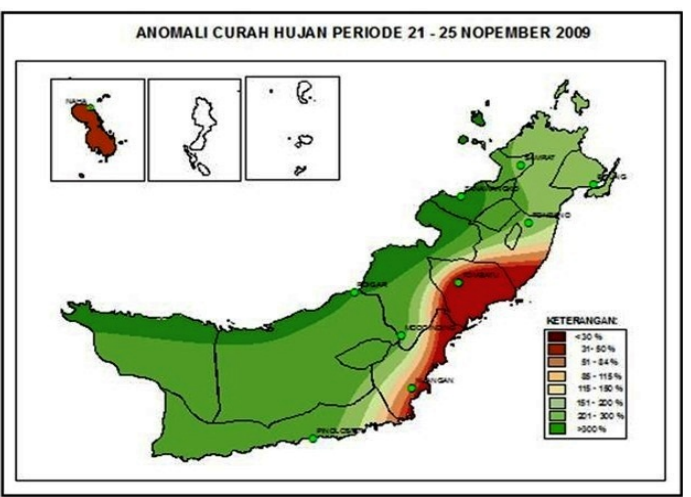

Gambar 20: Anomali curah hujan periode 21 - 25 November 2009.

lah utara Papua dan mencapai tahap depresi tropis (Tropical Storm) pada tanggal 23 September 2009. Pada tanggal 24 September Nida memasuki tahap Typhoon dengan intensitas angin maksimum 65 knot. Keadaan atmosfer sangat mendukung pertumbuhan siklon tropis Nida dan menyebabkan intensitasnya meningkat menjadi super typhoon. Citra satelit memperlihatkan mata/eye siklon yang cukup jelas saat mencapai intensitas maksimum dengan kecepatan angin maksimum mencapai 115 knot dan tekanan $905 \mathrm{hPa}$ pada tanggal 25 September. Angin yang sangat kencang dan kuat ini dapat meningkatkan tinggi gelombang laut hingga memasuki kategori yang sangat berbahaya. Pada tanggal 30 September siklon Nida menurunkan statusnya dari super typhoon hingga akhirnya melemah dan punah saat memasuki Pasifik Barat [11] (Gambar 19).

Siklon tropis Nida ini memberi dampak timbulnya daerah pertemuan angin yang memicu hujan salah satunya di sekitar Laut Sulawesi. Gelombang hingga 3 meter juga terjadi di Perairan Sangihe, Talaud, utara Halmahera dan Samudra Pasifik di sebelah Utara Papua [8]. Pada tahap awal pertumbuhannya peningkatan curah hujan $>150 \%$ terjadi hampir diseluruh wilayah Sulawesi Utara kecuali Sangihe, Tondano dan Nuangan sebagaimana terlihat pada Gambar 20.

Pola angin pada peta streamline memperlihatkan adanya tekanan rendah di sebelah timur Filipina menyebabkan pergerakan angin di atas wilayah Sulawesi Utara berpola konver-

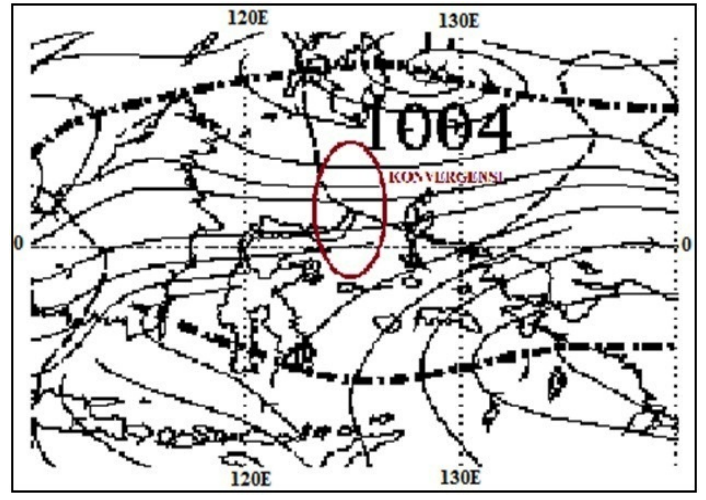

Gambar 21: Pola angin tanggal 22 November 2009 [8].

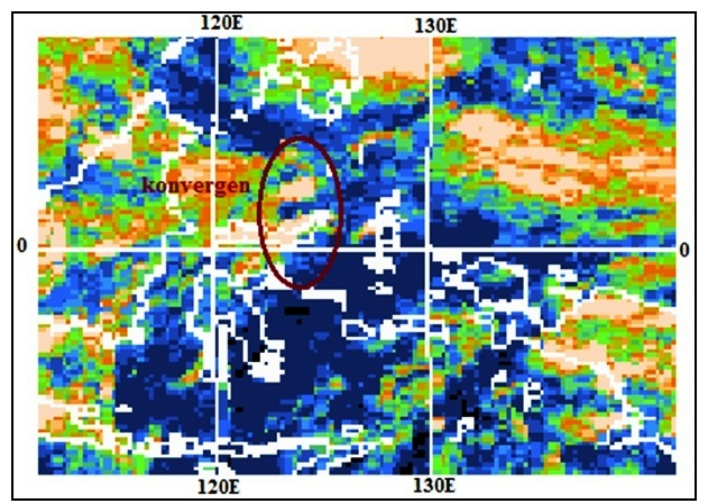

Gambar 22: Citra satelit tanggal 22 November 2009 pukul 09.00 UTC [9].

gen (Gambar 21). Pola ini menyebabkan bertambahnya curah hujan pada sebagian besar wilayah Sulawesi Utara. Citra satelit menunjukkan bahwa konsentrasi massa udara terjadi di Laut Sulawesi bagian barat yang berdampak pada semua wilayah Sulawesi Utara kecuali sebagian kecil wilayah Sulawesi Utara bagian utara dan tengah (Gambar 22).

Pada tahap tumbuh typhoon terjadi peningkatan curah hujan di Sulawesi Utara bagian selatan serta pengurangan curah hujan dibagian tengah dan utara (Gambar 23).

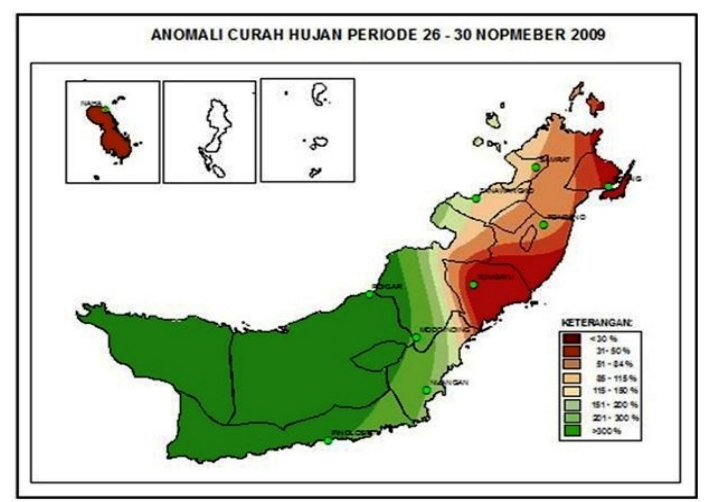

Gambar 23: Anomali curah hujan periode 26 - 30 November 2009. 


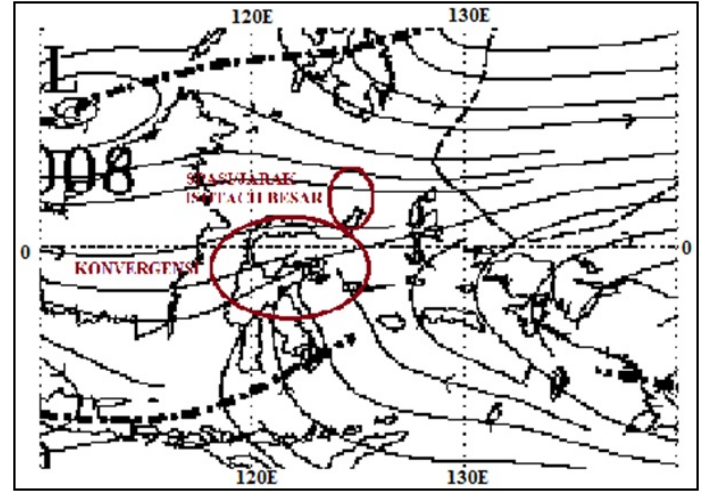

Gambar 24: Pola angin tanggal 27 November 2009 [8].

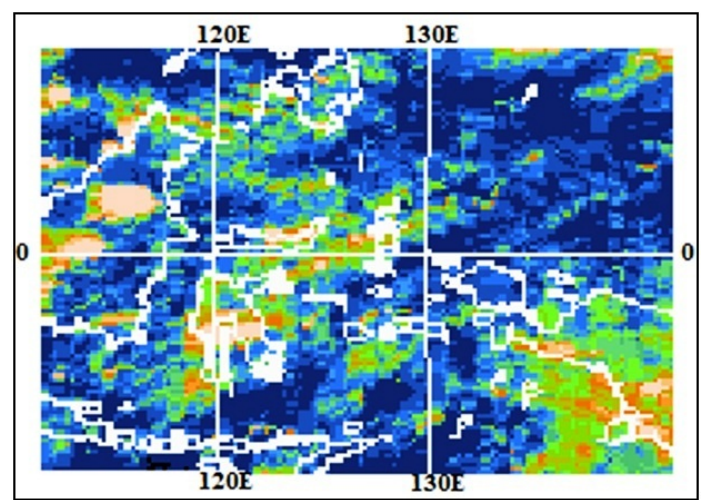

Gambar 25: Citra satelit tanggal 27 November 2009 pukul 12.00 UTC [9].

Pola angin pada periode yang sama memperlihatkan adanya daerah konvergensi di atas wilayah Sulawesi Utara bagian selatan yang menyebabkan penumpukkan massa udara pada sebagian besar wilayah tersebut. Di atas wilayah Sulawesi Utara bagian utara dan tengah pola angin dengan jarak/spasi isotach yang besar menyebabkan massa udara bergerak bebas sehingga hujan sulit terbentuk. Hal ini mengakibatkan wilayah tersebut mengalami penurunan curah hujan yang signifikan (Gambar 24). Citra satelit menunjukkan adanya konsentrasi massa udara diatas wilayah Sulawesi Utara tengah dan selatan yang berpotensi menambah curah hujan di wilayah tersebut (Gambar 25).

Pada tahap melemahnya siklon Nida hingga akhirnya punah curah hujan lebih banyak berkurang di sebagian besar wilayah Sulawesi Utara. Sebagian kecil wilayah Sulawesi Utara yaitu Pinolosian yang mengalami penambahan curah hujan (Gambar 26).

Pola angin pada peta streamline (Gambar 27) menunjukkan adanya daerah konvergensi yang cukup dekat dengan Sulawesi Utara sehingga menyebabkan massa udara tertarik ke daerah tersebut. Spasi/jarak isotach yang besar juga mengakibatkan pergerakan udara menjadi bebas dan mengurangi potensi hujan. Hal ini menyebabkan wilayah Sulawesi Utara kekurangan massa udara pembentuk hujan sehingga curah hujan di sebagian besar wilayah Sulawesi Utara berkurang ke-

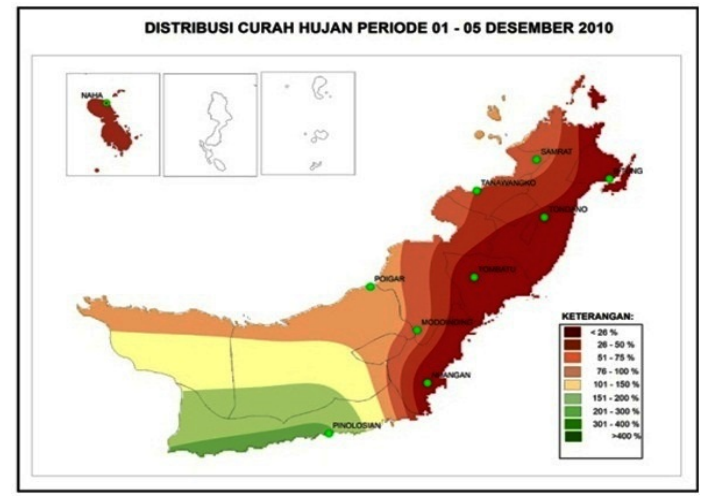

Gambar 26: Anomali curah hujan periode 1 - 5 Desember 2009.

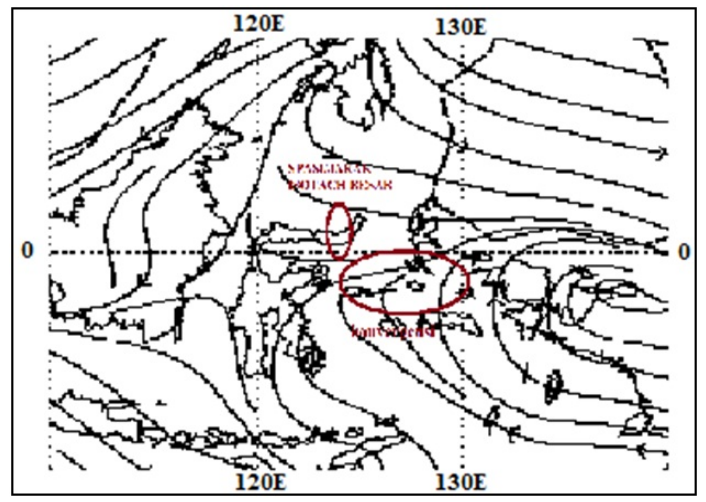

Gambar 27: Pola angin tanggal 04 Desember 2009 [8].

cuali Pinolosian (menunjukkan bahwa terjadinya penyimpangan di wilayah ini didominasi oleh pengaruh lokal). Citra satelit (Gambar 28) menggambarkan tidak adanya konsentrasi massa udara yang berpotensi mengakibatkan hujan di sekitar wilayah Sulawesi Utara. Sebagai akibatnya sebagian besar wilayah Sulawesi utara mengalami penurunan curah hujan.

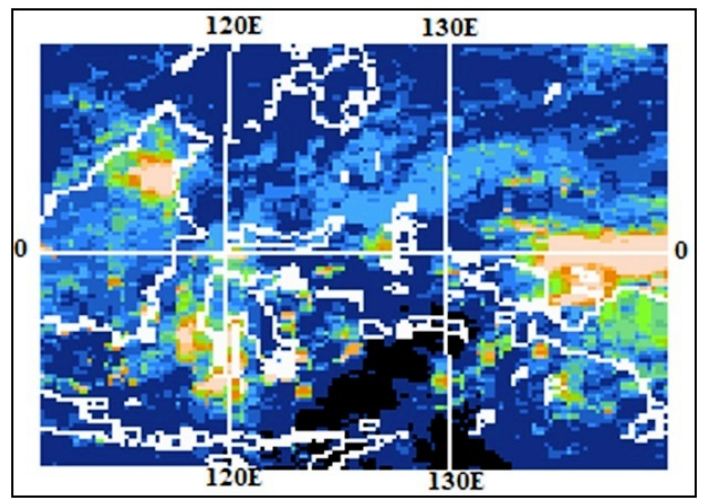

Gambar 28: Citra satelit tanggal 04 Desember 2009 pukul 00.00 UTC [9]. 


\section{SIMPULAN}

Berdasarkan penelitian yang dilakukan diperoleh simpulan sebagai berikut:

1. Dampak yang ditimbulkan masing masing siklon terhadap curah hujan di Sulawesi Utara berbeda beda tergantung karakteristik siklon dan kondisi lingkungannya, sebagai berikut:

- Pada siklon Nangka, tahap punah berpengaruh terhadap peningkatan curah hujan.

- Pada siklon Parma, tahap tumbuh berpengaruh menurunkan curah hujan dan tahap dewasa berpengaruh meningkatkan curah hujan.
- Pada siklon Nida, tahap tumbuh berpengaruh meningkatkan curah hujan, tahap dewasa dan punah berpengaruh menurunkan curah hujan.

2. Sifat hujan yang terjadi sebagai akibat adanya siklon berbeda-beda tergantung karakteristik masing masing siklon dan kondisi masing masing wilayah, yaitu:

- Pada siklon Nangka sifat hujan yang dominan terjadi di Sulawesi Utara adalah di atas normal.

- Pada siklon Parma sifat hujan yang lebih banyak terjadi di Sulawesi Utara adalah di atas normal.

- Pada siklon Nida sifat hujan yang lebih banyak terjadi di Sulawesi Utara adalah di bawah normal.
[1] E.B. Aguado, Understanding Weather and Climate (2nd ed. Prentice Hall Inc, New Jersey,2001).

[2] HK.B. Tjasyono, Meteorology of the Indonesia Maritime Continent, Volume I: Characteristics and Circulation of the Atmosphere (Indonesia Meteorological and Geophysical Agency (BMG), 2007).

[3] J.L. McBride, Tropical Cyclone Formation (Global Perspectives on Tropical Cyclones, WMO,1995).

[4] C.S. Ramage, Monsoon Meteorology (Academic Press Inc., London, 1971).

[5] -, Compendium of Lecture Notes for Training Class IV Meteorological Personnel, Volume II: Meteorology (World Meteorological Organization (WMO), 1976).

[6] A. Zakir, Kajian siklon tropis (2006) (http://www.scribd.com /doc/31289081/siklon-tropis-kajian, di akses tanggal 10 September 2010, pukul 16.50 WITA.)

[7] -, Tropical Cyclone Information, Japan Meteorological Agency
( http://www.jma.go.jp/en/typh/, di akses tanggal 10 September 2010, pukul 20.16 WITA).

[8] -, Gradient Level Wind Analysis Valid OOUTC, Bureau of Meteorology, (2009) (http://www.bom.gov.au/australia/charts/glw00z.shtml, di akses tanggal 11 September 2010, pukul 21.00 WITA).

[9] -, Satellite Pictures, Bureau of Meteorology, (2009) (http://172.19.1.1/ difacs/charts/index.satpix.html, di akses tanggal 15 September 2010 pukul 10.00 WITA).

[10] -, Prediksi El nino dan Awal Musim Hujan, BMKG, (2009) (http://data.bmkg.go.id/share/dokumen/prediksi-elnino\&-awalmusimhujan2009-2010.pdf, di akses tanggal 10 September 2010, pukul 20.00 WITA).

[11] -, TCWC Jakarta (2010), After Event Report BMKG. (2009) (http://meteo.bmkg.go.id/siklon/aer, di akses tanggal 17 Agustus 2012, pukul 18.00 WITA). 